\title{
Changes in phytoplankton production and upwelling intensity off $A$ Coruña (NW Spain) for the last 28 years
}

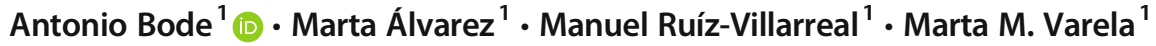 \\ Received: 25 September 2018 / Revised: 15 May 2019 / Accepted: 24 May 2019 / Published online: 10 June 2019 \\ (C) The Author(s) 2019
}

\begin{abstract}
The analysis of a 28-year-long (1989-2016) series of monthly measurements of chlorophyll concentrations and primary production rates at a shelf station off A Coruña (NW Spain) provided evidence of changes at several time scales that were only partly related to upwelling intensity. Chlorophyll determinations were made in acetonic extracts and primary production rates by the measurement of ${ }^{14} \mathrm{C}$-uptake by natural phytoplankton populations in simulated in situ conditions. Wavelet analysis revealed multiple modes of variation in both series, particularly at high frequencies, but some were only significant for part of the series. For instance, the seasonal cycle was not uniform through the series despite the annual repetition of maxima and minima. At multiannual time scales, both series were divided in three quasi-decadal periods characterized by significant increases in mean values. Fluctuations in chlorophyll and primary production covaried with changes in upwelling intensity at annual scales, but annual means showed low correlation. Changes in dissolved nutrient concentrations from continental sources were the likely drivers of the observed changes in productivity at large time scales. Increases in the decadal mean rates of production and concentrations of chlorophyll were driven by increased intensity of spring blooms associated to increased nutrients and low salinity water in the surface. In contrast, blooms caused by upwelling nutrients remained unchanged along the series. This study illustrates the complexity of interactions in coastal upwelling areas at large time scales, where changes in continental nutrient inputs may affect phytoplankton production more than variations in upwelling intensity.
\end{abstract}

Keywords Primary production · Upwelling · Nutrients · Quasi-decadal variability $\cdot$ NW Spain

This article is part of the Topical Collection on the 50th Internationa Liège Colloquium on Ocean Dynamics, Liège, Belgium, 28 May to 1 June 2018

Responsible Editor: Aida Alvera-Azcárate

Electronic supplementary material The online version of this article (https://doi.org/10.1007/s10236-019-01278-y) contains supplementary material, which is available to authorized users.

Antonio Bode

antonio.bode@ieo.es

Marta Álvarez

marta.alvarez@ieo.es

Manuel Ruíz-Villarreal

manuel.ruiz@ieo.es

Marta M. Varela

marta.varela@ieo.es

1 Instituto Español de Oceanografia, Centro Oceanográfico de A Coruña, Apdo, 130, 15080 A Coruña, Spain

\section{Introduction}

The primary production of the global ocean is expected to change in future climate scenarios. Most models predict for the end of this century a general decrease of ca. $30 \%$ of the values observed for the period between 1980 and 1990, mainly due to the expansion of oligotrophic areas in the subtropical and equatorial biomes (Behrenfeld et al. 2006; Polovina et al. 2008; Cabré et al. 2015). Such a reduction in production will translate in decreasing fisheries and mariculture production and will affect the global use of marine resources even beyond the direct demands for seafood (Chassot et al. 2010; Watson et al. 2015). The warming of the surface ocean in these regions enhances stratification and reduces the input of nutrients from subsurface layers, thus causing a reduction in primary production. Evidence from satellite-derived measurements indicated an increase of the low-chlorophyll areas in the subtropical gyres of the main oceans (Behrenfeld et al. 2006; Polovina et al. 2008). Even when some of these changes can be attributed to photoacclimation (Behrenfeld et al. 2016), the 
decreasing nutrient inputs would still limit primary production in these regions (Jang et al. 2011; Chust et al. 2014).

However, other regions are experiencing increases in primary production (Malone et al. 2016). For instance, the loss of sea ice and the increase in the growing season have caused an increase of $20 \%$ in annual primary production in the Arctic from 1998 to 2010 (Brown and Arrigo 2012) but this trend may be reversed if nutrient inputs are insufficient (Tremblay and Gagnon 2009). In contrast, a lower extent and duration of winter sea ice caused a decrease in production in Antarctic waters (Ducklow et al. 2013).

Most of the studies were concerned with production based on new nutrients (i.e., those provided from external sources to the photic zone), but a significant fraction of total primary production is based on nutrients regenerated in situ (Capone et al. 2008). Because plankton respiration increases faster with temperature than phytoplankton primary production (LopezUrrutia et al. 2006), the warming of surface waters would have a positive feedback on heterotrophy, thus increasing regenerated nutrients and productivity. Models based on the predicted warming during this century envisage an overall increase in productivity, and less export and capture of $\mathrm{CO}_{2}$, caused by the enhanced productivity by regenerated nutrients (Kvale et al. 2015).

One of the main contributors to global primary production is the eastern boundary upwelling ecosystems (EBUS). Covering less than $3 \%$ of the world's ocean surface, they account for between 10 and $20 \%$ of oceanic production (Messié et al. 2009; Malone et al. 2016), have a significant role in the climate system (Large and Danabasoglu 2006), and contribute to $40 \%$ of the reported global fish catch (Pauly and Christensen 1995; Capone and Hutchins 2013). An increase in primary production in EBUS has been put forth as a consequence of the intensification of the alongshore winds caused by the differential warming of the land and the ocean surface (Bakun 1990). The increase in wind speed would enhance the input of nutrients from upwelled waters and thus primary production. Evidence for these increases has been provided by models (Rykaczewski et al. 2015) and observations (Demarcq 2009), but these also revealed that the large heterogeneities in the wind changes at regional scales were mainly due to the poleward displacement of the high atmospheric pressure cells rather than an effect of increasing land-sea temperature differences (Rykaczewski et al. 2015). In addition, regenerated nutrients amplify the initial production triggered by the upwelling, thus increasing total production (e.g., Alvarez-Salgado et al. 1997). Furthermore, palaeocological studies suggest the participation of additional factors, as the inputs of continental waters, affecting phytoplankton composition and production in upwelling ecosystems (Abrantes et al. 2011).

In the case of the EBUS including the region from $\mathrm{NW}$ Africa to the NW Iberian Peninsula, primary production is largely driven by the seasonal change in the dominant alongshore winds favoring the upwelling of subsurface waters (Arístegui et al. 2006). Eastern North Atlantic Central Waters (ENACW) are advected to the coast in the period between March and October, when the winds are predominantly equatorward, introducing large amounts of new nutrients into the photic layer and enhancing primary production (AlvarezSalgado et al. 1997; Alvarez-Salgado et al. 2002). Changes in productivity were described at geological time scales (e.g., Abrantes et al. 2011), but there is contradictory evidence as to the direction of changes in recent times and the projections for the future. Recent intensification of upwelling was described for the African coast (McGregor et al. 2007), but other analysis of wind data showed differences in trends at subregional scale (Alvarez et al. 2008; Pérez et al. 2010; Santos et al. 2011), a general weakening in the region (Pardo et al. 2011) or no clear evidence of upwelling decrease (Barton et al. 2013; Benazzouz et al. 2015). Indeed, estimations based on regional climate models predict an increase in upwelling-favorable winds in the region (Casabella et al. 2014). Satellite-derived chlorophyll series did not reveal a consistent trend through the region (Bode et al. 2011; Alvarez et al. 2012: Benazzouz et al. 2015) but in situ determinations near the coast suggest large year to year variations (Bode et al. 2011) or even increases at decadal time scales (Pérez et al. 2010). The continuous series of in situ primary production rate determinations available in the region showed a sustained increase for the period 1989 2010 at an upwelling site (A Coruña), while a general decrease in primary production was observed in Cudillero, on the northern Iberian coast, where upwelling has lower influence (Bode et al. 2011).

The objective of this study is to analyze periodic and longterm changes in the series of phytoplankton chlorophyll and primary production rates measured off A Coruña (Galicia, NW Spain) between 1989 and 2016 in relation to changes in upwelling intensity and nutrient inputs. The focus is on the changes observed in the whole water column, as the phytoplankton production occurs in the photic layer but is affected by the nutrients provided from deep layers during upwelling events.

\section{Methods}

\subsection{Sampling}

The study site was station E2CO $\left(43^{\circ} 25.32^{\prime} \mathrm{N}, 8^{\circ} 26.22^{\prime} \mathrm{W}\right.$, $80 \mathrm{~m}$ deep) from the RADIALES program (http://www. seriestemporales-ieo.com/) of the Instituto Español de Oceanografía (IEO, Spain). The station was visited at approximately monthly intervals since 1989 with collection of water samples at 7 depth levels using Niskin bottles after CTD casts (Seabird SBE25). Since 2002 a Seabird Compact Carousel (SBE32C) was employed to facilitate the sampling 
of water during the CTD profiles. The CTD was equipped with a LiCor underwater radiometer for the determination of photosynthetically active radiation (PAR) profiles. Water samples were collected to determine phytoplankton chlorophyll and production, inorganic nutrients, dissolved oxygen and seston carbon and nitrogen. More details of sampling and description of seasonal variations at this station can be found elsewhere (Casas et al. 1997; Bode et al. 2015). In this study, we analyzed the full series of observations between January 1989 and December 2016.

\subsection{Measurements}

Phytoplankton chlorophyll (Chl) was measured on plankton collected on Millipore cellulose acetate $0.8 \mu \mathrm{m}$ pore size (until 1992) or Whatman GF/F filters, extracted in $90 \%$ acetone overnight and measured fluorometrically (Parsons et al. 1984). From the year 2000 onwards, the extracts were analyzed using the spectrofluorometric method (Neveux and Panouse 1987) and intercalibration adjustments between methods were made to ensure the compatibility of the series for the entire sampling period. As a result of the intercalibration, fluorometric measurements were multiplied by 0.65 to estimate spectrofluorometric Chl. Primary production rates (PP) were estimated by measuring the uptake of ${ }^{14} \mathrm{C}$-labeled bicarbonate in samples incubated in simulated temperature and irradiance conditions equivalent to those of the original sampling depth using running surface water and neutral density screens, respectively (Bode and Varela 1998; Bode et al. 2011). Samples for primary production determinations corresponded to depths receiving $100 \%, 50 \%, 25 \%, 10 \%$, and $1 \%$ of surface PAR, as measured with the CTD PAR sensor. Two $100 \mathrm{~mL}$ replicates plus one dark bottle were filled on board with water of each depth, transported the laboratory (within $2 \mathrm{~h}$ of collection) and inoculated with $148( \pm 57) \mathrm{kBq}$ of $\mathrm{NaH}^{14} \mathrm{CO}_{3}$. Incubations were made under direct sunlight at the laboratory (A Coruña) for 2-3 h at noon and were terminated by filtration on the same type of filters used for chlorophyll determinations. The excess ${ }^{14} \mathrm{C}$ was removed from the filters by adding $10 \% \mathrm{HCl}$ overnight and the radioactivity determined in a liquid scintillation counter (LKB Wallac 1409 until 2006 and Packard TriCARB 2900TR thereafter) using automatic quenching correction with internal standards. Scintillation cocktails were Insta-Gel (Perkin Elmer) until 1996 and Ultima-Gold XL (Perkin Elmer) thereafter. Rates of PP were corrected for inorganic carbon incorporation in the dark bottle and expressed as $\mathrm{mg} \mathrm{C} \mathrm{m}^{-3} \mathrm{~h}^{-1}$ for each depth level.

Inorganic nutrient concentrations (nitrate+nitrite, phosphate, and silicate) were determined in samples preserved frozen in polyethylene vials $\left(-20^{\circ} \mathrm{C}\right)$ by segmented flow analysis using a Technicon AA-II (1989-2006), a Bran-Luebbe AA3 (2007-2012), or a Seal Analytics QuAAttro 39 (2013-
2016) analyzer. The colorimetric methods employed were based in those described by Grasshoff et al. (1983). Dissolved oxygen was determined in duplicate $125-\mathrm{mL}$ bottles using the Winkler titration procedure (Parsons et al. 1984) and particulate organic carbon and nitrogen (POC and PON, respectively) in seston collected on Whatman GF/C (19891992) or GF/F filters analyzed in a Perkin Elmer CHN 2400 (1989-2009) or a Carlo Erba CHNSO 1108 elemental analyzer (since 2010). Nutrient anomalies relative to the expected concentrations in ENACW (the main input from upwelling) were determined as the difference between the observed concentrations in bottom water (70 $\mathrm{m}$ depth) of sampling dates during upwelling events and ENACW nutrient concentrations, the latter estimated from in situ temperature using the equations provided by Álvarez-Salgado et al. (AlvarezSalgado et al. 2002). Such equations were determined with data from 14 cruises in the NW Iberian upwelling system between 1977 and 1998, excluding data from stations with water depth $<1000 \mathrm{~m}$ to avoid the nutrient enrichment in shelf bottom waters due to intense mineralization. Detailed analysis of nutrient influence on the $\mathrm{Chl}$ and PP series was made by considering two main sources of nutrients for primary production in the study area: the bottom waters during the upwelling period (March to October) and the continental waters (river discharge and runoff) affecting the surface mainly during the winter-spring period (February to May).

Upwelling intensity (UI) was obtained from the Ekman transport derived from surface winds (http://www. indicedeafloramiento.ieo.es/) in a cell of $1^{\circ} \times 1^{\circ}$ centered at $44^{\circ} \mathrm{N}, 9^{\circ} \mathrm{W}$, using data from atmospheric pressure at sea level derived from the WXMAP model (González-Nuevo et al. 2014). Positive values of this index (expressed in $\mathrm{m}^{3} \mathrm{~s}^{-}$ ${ }^{1} \mathrm{~km}^{-1}$ ) indicate net upwelling periods when surface water is transported offshore while negative values indicate an accumulation of surface water against the coast (downwelling). For the purpose of the present study, 6-hourly UI values were averaged over the 15 days preceding each sampling event of E2CO station, as previous studies indicated that Chl was correlated with upwelling events occurring several days before sampling (e.g., Nogueira et al. 1997).

Influence of runoff during spring was estimated from rainfall observations in A Coruña (Agencia Estatal de Meteorologia, AEMET, Spain). In this study, rainfall data were accumulated for the 15 days preceding each sampling event at sea.

Raw data of water and plankton observations used in this study can be accessed through the PANGAEA repository (https://doi.pangaea.de/10.1594/PANGAEA.885413).

\subsection{Statistics}

For the purpose of this study, values of all variables were summarized for each sampling date. Chlorophyll, primary 
production rates, $\mathrm{POC}$ and $\mathrm{PON}$ were integrated, and nutrient and oxygen data were averaged in the euphotic zone ( $1 \%$ of surface PAR). The depth of the euphotic zone varied between 14 and $53 \mathrm{~m}$ and showed no temporal trends (Online Resource 1). The original PP hourly rates were not scaled to daily rates to preserve the original series and to avoid assumptions on the appropriate scaling factors. Other studies on subsets of the same series provide various estimates of daily production rates at the same station (e.g., Bode and Varela 1998; Bode et al. 2011). Temperature and salinity measurements were represented by surface values (SST and SSS, respectively) and nutrients provided by the upwelling by their concentrations in the bottom layer $(70 \mathrm{~m})$. Time series of all variables were explored for the presence of outliers, normality, homoscedasticity, and colinearity among variables (e.g., Zuur et al. 2010) using the PAST v3.17 package (Hammer et al. 2001).

Multiannual periods of change in Chl, PP, and UI were first identified using the cumulative sum of the mean distances method (Ibañez et al. 1993) by removing from each temporal observation the mean of the time series and plotting the cumulative sum of residuals. Changes in the slope of the cumulative sum curve from positive to negative or vice versa indicate phases for which the mean of the data is higher or lower than the mean of the original time series. Further analysis of periodicity at small (months) and large time scales (years) in the time series was made by computing the continuous wavelet transformation on each time series after normalization $\left(\log _{10}\right.$-transformation) and regularization to periods of 30 days using the quadratic interpolation method in PAST. The wavelets enable the extraction of time-dependent amplitude cycles related to frequencies (Torrence and Compo 1998; Cazelles et al. 2008). The plot of the squared correlation strength with the scaled mother Morlet wavelet allowed for inspecting the series at small, intermediate, and large frequencies simultaneously. The significance of the identified periodicities was assessed with a $\chi^{2}$ test and the cone of influence computed to discard boundary effects (Torrence and Compo 1998). Wavelet analysis and related tests were made with PAST. The influence of environmental variables on Chl and PP series was first analyzed using the annual means of each series. Environmental variables were first normalized, centered, and standardized. The significance of auto- and cross-correlation between series of variables was determined after Davis (1986). Correlation analysis was used to remove highly correlated variables (Online Resource 2) and SST, SSS, mean oxygen, POC and bottom water nutrient concentrations, along with UI were retained for a principal component analysis (PCA) reflecting the main modes of variability in these series. The series of $\mathrm{Chl}$ and PP were then projected on the space of the first components to identify the main associations. In a second step, changes in the environmental variables between the phases of $\mathrm{Chl}$ and PP series identified with the cumulative sums method were analyzed at intra-seasonal scale. The significance of variability in Chl, PP, and environmental variables was determined using permutational ANOVA tests (PERMANOVA) computed with PAST.

\section{Results}

\subsection{Seasonality vs. Iong-term periodicity}

All series recorded during the last 28-year period showed recurrent maxima and minima each year but also multiannual periods of relatively minor change (Online Resource 3). As described in previous studies, minimum water temperature values (and maximum nutrient concentrations) were observed in late winter in surface waters, where the converse situation was more likely in summer (e.g., Casas et al. 1997). The frequent incidence of upwelling events during most of the year, but mainly between March and October, caused the cooling and nutrient enrichment of the surface and subsurface layers at values near those of the late winter minimum. Such changes were reflected by the high variability in the distribution of $\mathrm{Chl}$ and PP, with peaks affecting the whole photic zone during the entire upwelling season each year (Fig. 1). However, the magnitude of the annual changes varied at low frequencies, as shown by the accumulated monthly anomalies. The entire series of $\mathrm{Chl}$ and PP could be divided into three periods of 9-10 years, when there were abrupt changes in the slope of the accumulated anomalies of the series (mainly for Chl but also for PP). The first period (1989-1997) was characterized by a decreasing trend in the anomalies, with $\mathrm{Chl}$ and PP values below the total mean for the series. This decrease was stabilized in the second period (1998-2006), but the values were still lower than the mean. Finally, a third period (2007-2016) was characterized by an increasing trend in the anomalies and $\mathrm{Chl}$ and PP values finally reaching values above the mean. Notwithstanding the general synchrony observed between $\mathrm{Chl}$ and PP, some differences were apparent, mainly related with the slow but persistent increase of the PP anomalies during the central period (1998-2006).

Annual repetition of maximum and minimum values was also present by the upwelling index series, but in this case, the multiannual periods emerging from the accumulated anomalies were clearly different from those of Chl and PP (Fig. 1). Two main periods (1989-2003 and 20042016) showed a nearly symmetrical bell pattern of UI: increasing the positive anomalies to a maximum near the center of the period and then decreasing again to low values. It must be noted that positive anomalies dominated in both periods, indicating that the values were mainly 
Fig. 1 Time series (thin lines) of a photic-zone integrated chlorophyll (Chl, $\mathrm{mg} \mathrm{m}^{-2}$ ), b primary production $(\mathrm{PP}$, $\mathrm{g} \mathrm{C} \mathrm{m}^{-2} \mathrm{~h}^{-1}$ ), and $\mathbf{c}$ Ekman transport (upwelling index, $\mathrm{m}^{3} \mathrm{~s}^{-1} \mathrm{~km}^{-1}$ ) and the corresponding accumulated anomalies from the mean value of each series (thick lines). The vertical dashed lines indicate three phases of change in $\mathrm{Chl}$ and PP (a)

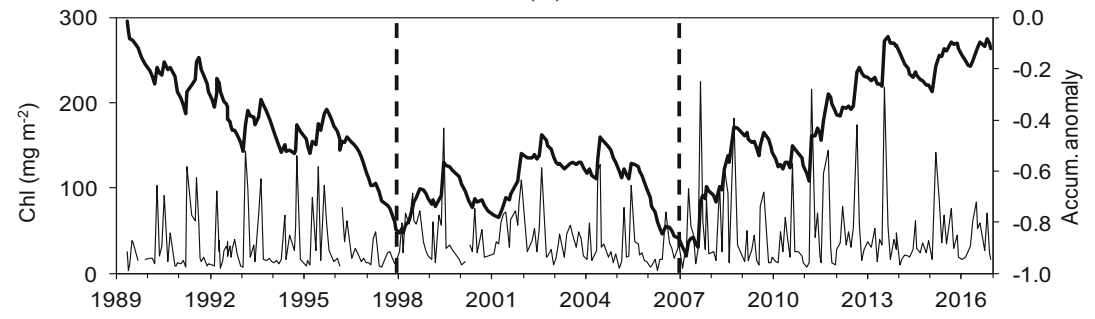

(b)

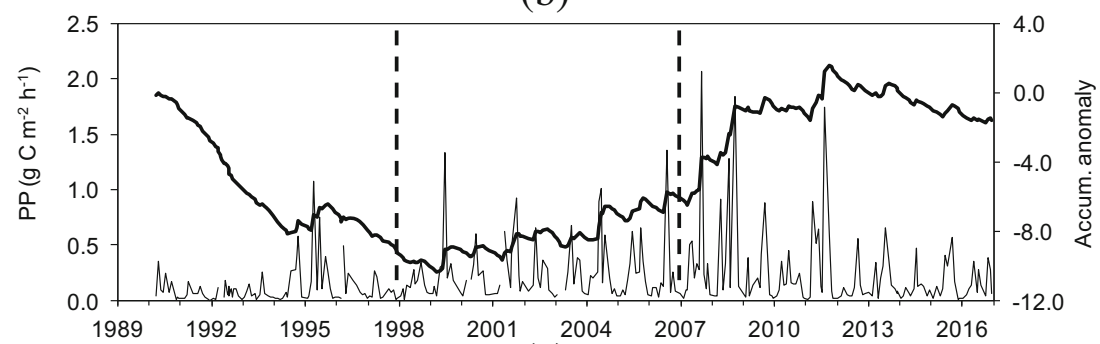

(c)

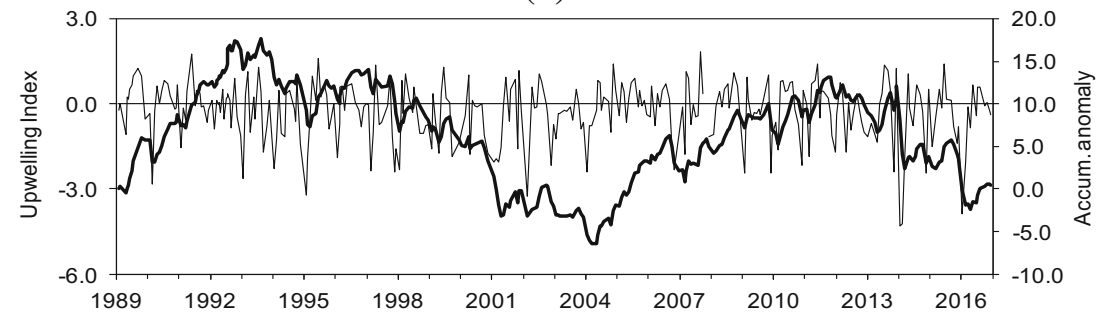

above the mean of the whole series, with negative anomalies concentrated in the transition between periods at the middle of the series. When compared with the phases described for Chl or PP, UI anomalies did not show a consistent pattern of change, as values increased and decreased during each of the periods. In addition, the mean values of UI for the three periods identified for $\mathrm{Chl}$ and PP were not significantly different (PERMANOVA, $F_{2,326}=0.945, p=0.381$ ).

A further comparison of monthly, annual, and longterm variability was provided by the wavelet analysis, showing a significant annual periodicity (i.e., maxima near a 12-month period) but also at other frequencies in all variables (Fig. 2). For instance, the seasonality in $\mathrm{Chl}$ was not always significant but only in the initial years of the periods 1989-1997 and 1998-2006, while since 2007, there were even two annual peaks (i.e., significant maxima near 6- and 12-month periods). In addition, there was significant periodicity in $\mathrm{Chl}$ at frequencies between 3 and 5 years. Similar periodicities were observed for the PP series, but in this case, the significance of the annual seasonality was restricted to the phases after 1998 and the bimodal peaks to only some years of the last period (2007-2016). In both cases, and because of the total length of the series, the quasi-decadal phases identified with the accumulated anomalies in Fig. 1 appeared at the boundaries of the cone of influence (i.e., near 9 years) but only were significant for PP. In contrast, the variability in UI was significant at multiple low and high frequencies but maximum values concentrated in all cases at the annual frequencies, particularly in recent years. The symmetry of the whole UI series was indicated by the relative maximum in the local power spectrum at frequencies near 8 years (i.e., 6.6 in the $\log _{2}$ scale).

As indicated with the wavelet analysis, the monthly distributions of Chl and PP series varied significantly between phases (Fig. 3). While the distribution of monthly means of both variables was quite homogeneous for the first two phases, there was a marked peak during the first half of the year for the 2007-2016 phase (Wilcoxon signed rank test, $p<0.05$ ). Consequently, means for the winter-spring season in 2007-2016 were higher than those in previous periods (PERMANOVA and Bonferroni tests, $p<0.05$, Online Resource 4). When considering whole phases, the mean values of $\mathrm{Chl}$ and $\mathrm{PP}$ increased significantly through the study period (PERMANOVA and Bonferroni tests, $p<0.05$, Fig. 4).

\subsection{Environmental variability}

From the PCA on the selected annually averaged variables, three main components accounting for 35.4, 17.9, 


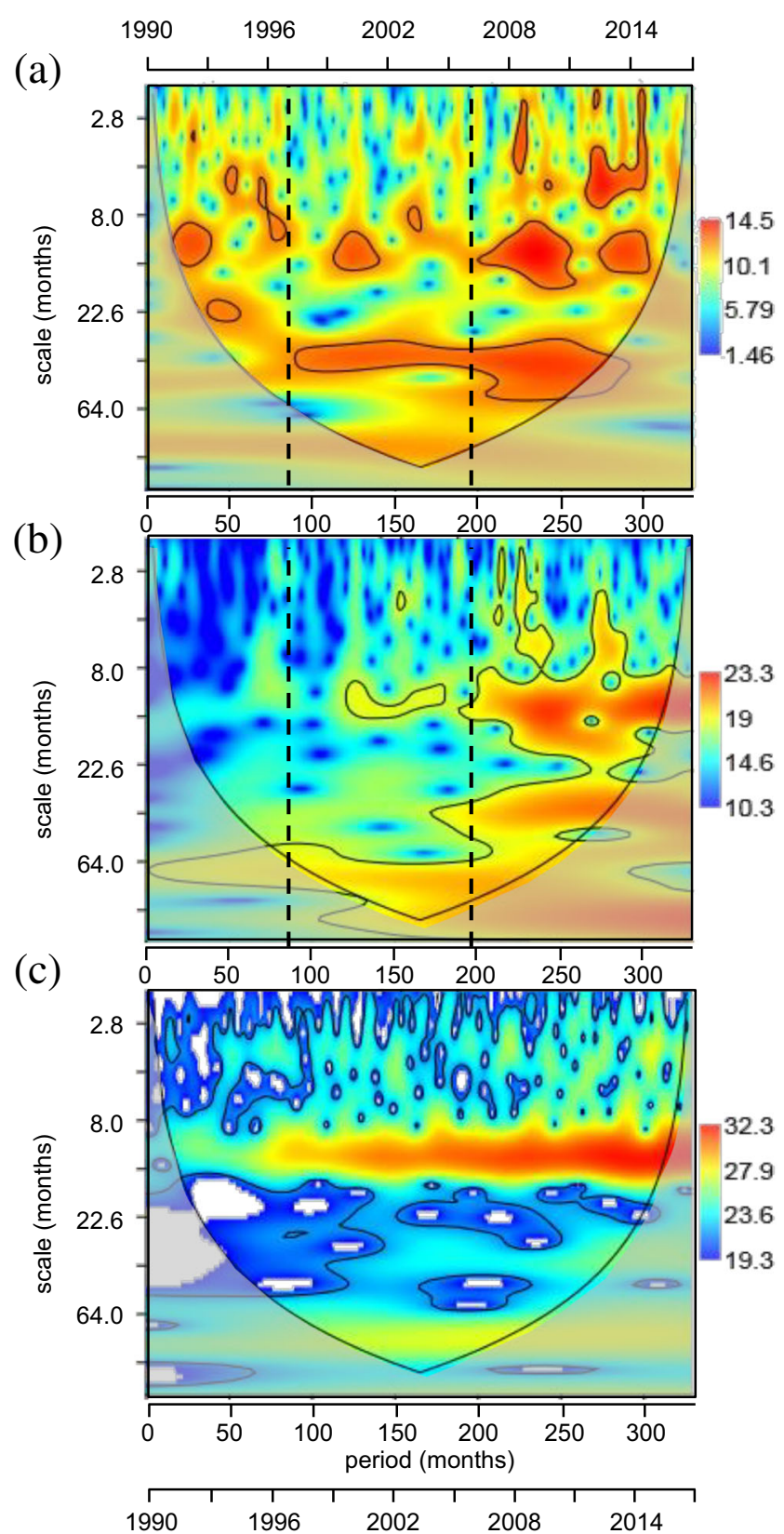

Fig. 2 Local wavelet power spectrum of photic-zone integrated a chlorophyll, b primary production, and $\mathbf{c}$ upwelling index time series. The $X$-axis (interval, months) indicates the length of the series and the $Y$-axis the $\log _{2}$ time scale, with the signal observed at a scale of only two consecutive data points at the top, and at a scale of one fourth of the whole sequence at the bottom. The continuous black lines denote the 5\% significance areas and the cone of influence (i.e., region of the wavelet spectrum in which edge effects become important). The colors indicate the squared correlation strength of each series with the scaled mother wavelet. The vertical dashed lines indicate the three phases identified in Fig. 1

and $16.7 \%$ of total variance were selected (Fig. 5, Online Resource 5). The first component was positively correlated mainly with nitrate and phosphate concentrations and salinity, and negatively with POC and surface (a)

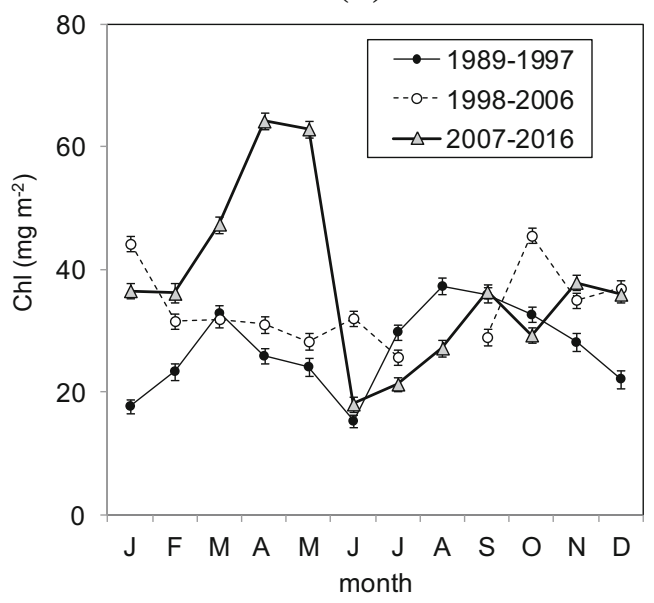

(b)

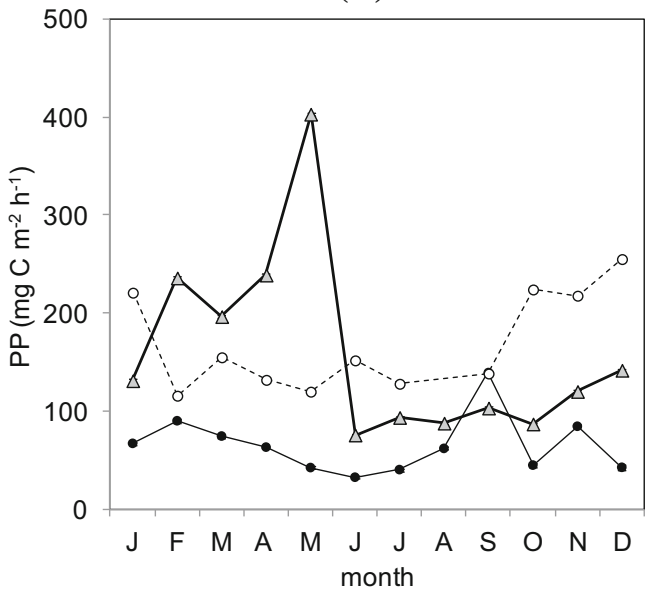

Fig. 3 Mean $( \pm$ SE) monthly values of photic-zone integrated a chlorophyll $\left(\mathrm{Chl}, \mathrm{mg} \mathrm{m}^{-2}\right.$ ) and b primary production (PP, $\mathrm{mg} \mathrm{C} \mathrm{m} \mathrm{h}^{-1}$ ) for the different phases identified in Fig. 1

temperature. In turn, the highest positive correlations of the second component were observed for oxygen concentration, while the main negative correlations were those for silicate. The third component was positively correlated with all variables except with salinity, which showed a marked negative correlation. Therefore, the first component separated years of relatively high nutrient concentration, low water temperature, and dominance of saline waters from those of high concentration of seston, higher temperature, and lower salinity and nutrient concentrations. The second component highlighted the opposite relationship between oxygen and silicate concentrations, and the third component appeared related with years with relatively high inputs of nutrient-rich continental waters by runoff (i.e., low salinity waters in Online Resource 2). The mean upwelling intensity had a relatively weak correlation with all three PCA components and the same occurred with Chl and PP when projected on the PCA 
(a)

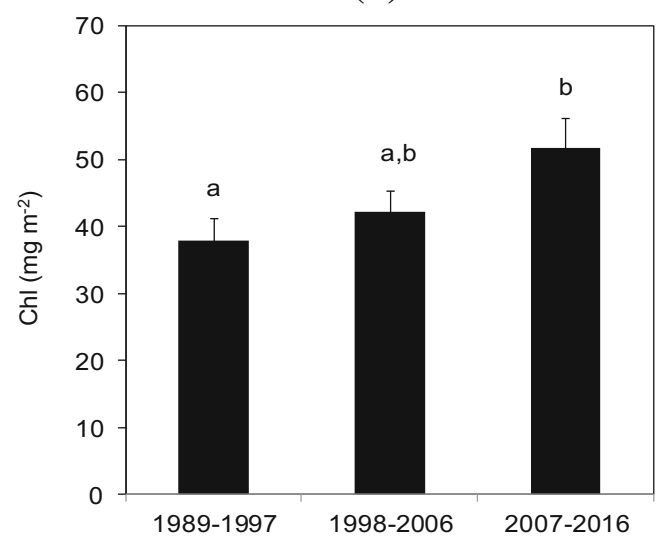

(b)

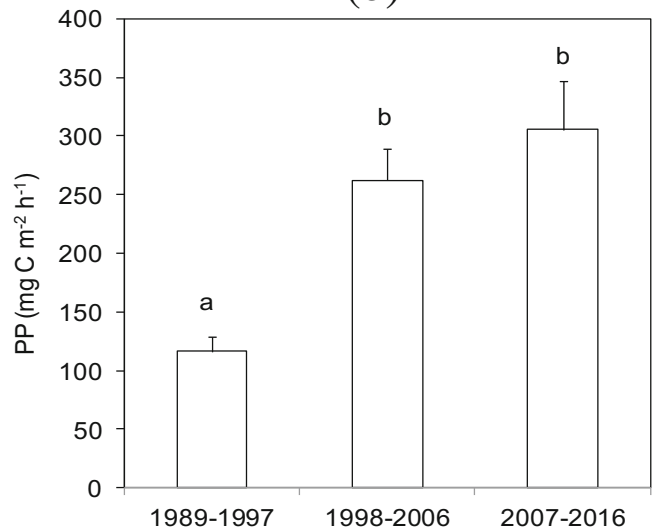

Fig. 4 Mean $( \pm$ SE) annual values of euphotic-zone integrated a chlorophyll ( $\mathrm{Chl}, \mathrm{mg} \mathrm{m}^{-2}$ ) and b primary production (PP, $\mathrm{mg} \mathrm{C} \mathrm{m}{ }^{-2} \mathrm{~h}^{-1}$ ) for the different phases identified in Fig. 1. The letters above each bar identify significant means (PERMANOVA and Bonferroni tests, $p<0.05$ )

space (Fig. 5). For the latter variables, the highest correlations were positive with the third component, followed by those with the first (also positive) and the second (negative) components. All these correlations indicate that $\mathrm{Chl}$ and PP at annual time scales were rather influenced by a combination of variables, mainly related with the nutrient inputs, than by a simple response to upwelling intensity.

Mean nutrient concentrations in bottom waters, except silicate, were similar for the three phases (Fig. 6). Furthermore, there was not a clear pattern of change in the distribution of anomalies from the reference ENACW nutrient concentrations between phases (Online Resource 6). Interannual variability was high and anomalies were mostly positive. In contrast, there was a significant increase in mean concentrations of all nutrients in surface waters from the first to the last phase of the study (Fig. 6). Such increases were concurrent with a significant decrease of mean salinity and an increase in rainfall, particularly after the phase between 1989 and 1997 (PERMANOVA and Bonferroni tests, $p<0.05$, Fig. 7). (a)

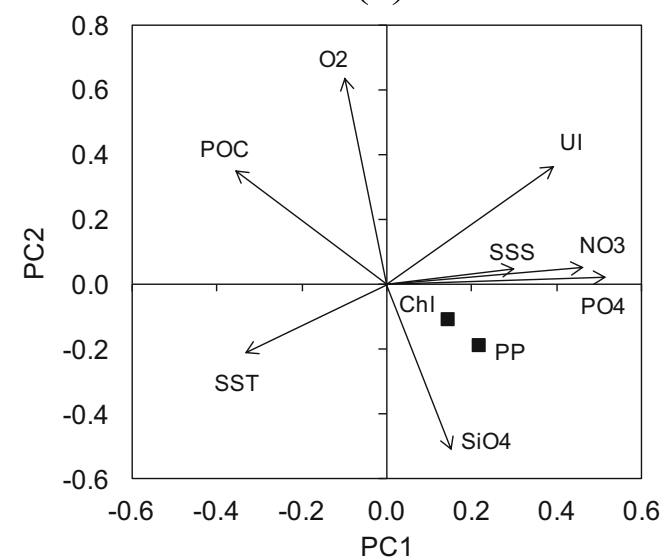

(b)

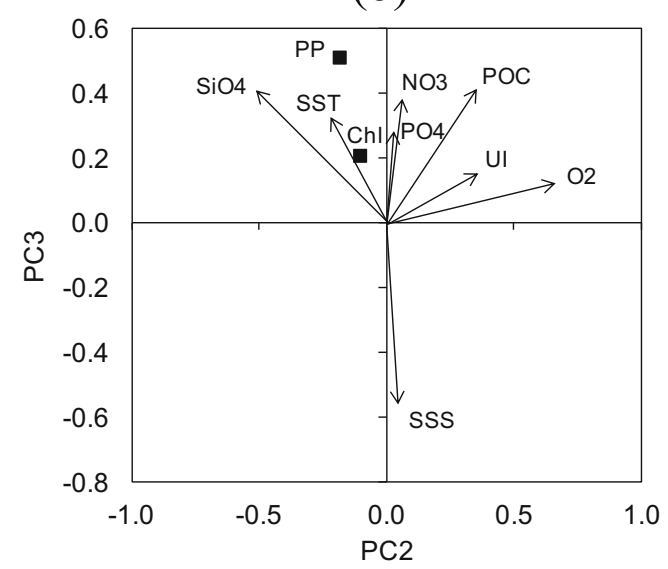

Fig. 5 Projection of photic-zone integrated chlorophyll $(\mathrm{Chl})$ and primary production (PP) on the space of the 3 principal components (PC1, PC2, and $\mathrm{PC} 3$ ) extracted from the series of environmental variables. Correlations between the environmental variables and the principal components are indicated by vectors. SST sea surface temperature, SSS sea surface salinity, $\mathrm{NO} 3, \mathrm{PO} 4$, and $\mathrm{SiO} 4$ total nitrate, phosphate, and silicate concentration near the bottom, $\mathrm{O} 2$ mean oxygen concentration in the photic zone, POC mean particulate organic carbon in the photic zone, UI upwelling index

\section{Discussion}

\subsection{High- vs. low-frequency oscillations}

The analysis of a series spanning 28 years showed significant quasi-decadal variability in primary production in a coastal site affected by upwelling. This result confirms previous analysis of a shorter version of the series for the period 1989-2006 (Bode et al. 2011) and aligns with similar quasi-decadal variability found in other EBUS (Heymans et al. 2004; Lavaniegos and Ohman 2007; Demarq Demarcq 2009). Changes in the regional climate affecting wind regimes and currents were often invoked as the most likely drivers of the observed variability at long-term scales. For instance, Chavez et al. (2011) noted that El Niño-Southern Oscillation (ENSO) anomalies in 1997-1998 strongly depressed primary 
(a)

upwelling : bottom water
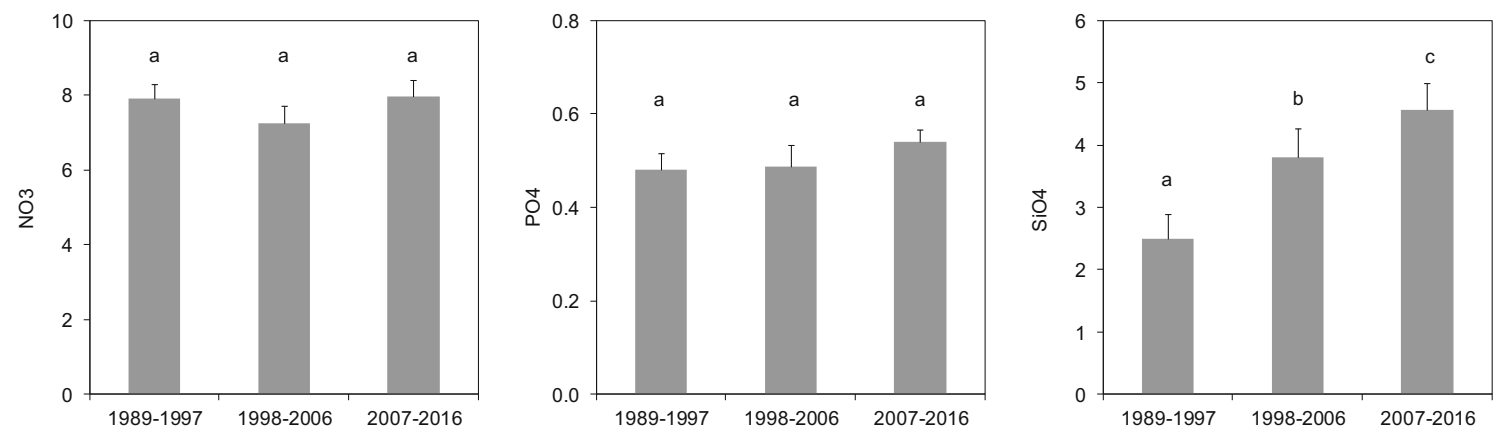

(b)

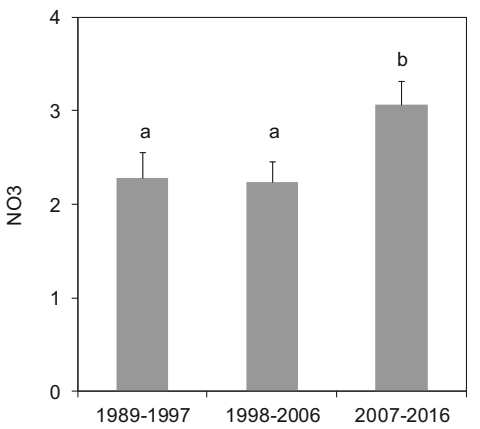

\section{spring: surface water}
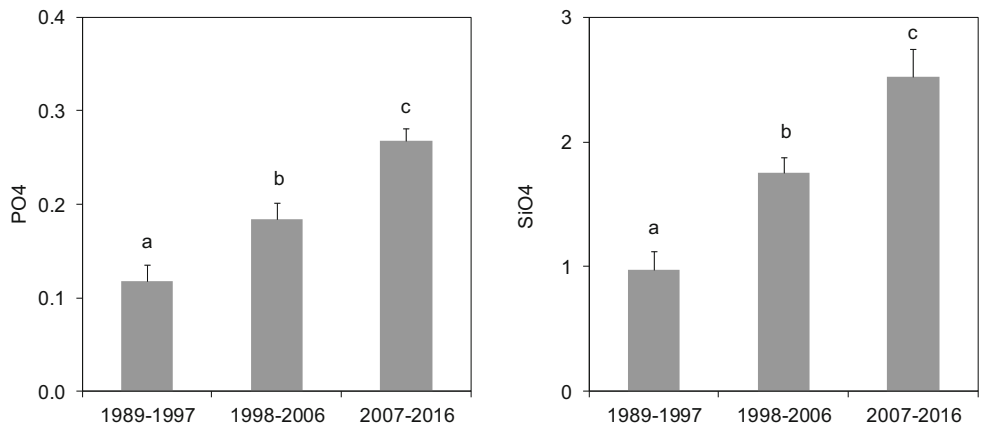

Fig. 6 Mean $( \pm \mathrm{SE})$ values of nitrate $\left(\mathrm{NO}_{3}\right)$, phosphate $\left(\mathrm{PO}_{4}\right)$, and silicate $\left(\mathrm{SiO}_{4}\right)$ concentrations $\left(\mu \mathrm{mol} \mathrm{L} \mathrm{L}^{-1}\right)$ in a bottom water during upwelling events (March to October) or $\mathbf{b}$ in surface water during spring

(February to May) for the different phases identified in Fig. 1. The letters above each bar identify the significant groups (PERMANOVA and Bonferroni tests, $p<0.05$ )

productivity in the coast of California because of the reduced input of nutrients. Thereafter, a general increase in primary productivity was recorded in several observational series across the Pacific and Atlantic oceans, including the one studied here, in coincidence with a shift in climatic modes (Chavez et al. 2011). However, high mesoscale variability caused spatial differences in nutrient inputs and Chl (Mantyla et al. 2008; Nezlin et al. 2017), thus complicating the identification of local versus regional or climatic drivers. Notwithstanding the significant correlation at monthly time scales between $\mathrm{Chl}$ or PP and upwelling intensity, either considering in situ measurements (Bode et al. 2011; this study), satellite observations (Alvarez et al. 2012; Picado et al. 2015) or estimated from biogeochemical budgets (Alvarez-Salgado et al. 2002; Piedracoba et al. 2008), there is still a substantial fraction of their variability unexplained by the wind regime in Galicia. Additional factors, as an increase in the remineralization of organic matter, were proposed as relevant drivers of phytoplankton productivity, particularly in coastal waters (e.g., Pérez et al. 2010). Because of the rapid response of phytoplankton to wind, seasonal variability in $\mathrm{Chl}$ and $\mathrm{PP}$ can be high, as observed in this study (Figs. 2 and 3). Indeed, significant variation in these variables was found for winter-spring and summer-autumn periods unmatching the typical seasonality of upwelling (spring-summer) and nonupwelling (autumn-winter) periods. Other studies of time series also pointed out the difficulty of identifying a typical or average seasonal cycle both for phytoplankton (Kim et al. 2009; Silva et al. 2009; Bode et al. 2009; Alvarez et al. 2012) and zooplankton variables affected by upwelling (Bode et al. 2009; GonzálezGil et al. 2015; Buttay et al. 2016). In consequence, the highfrequency (i.e., monthly) variability of plankton translates also in high interannual variability in these series. In contrast, seasonal cycles characterized by one annual mode in spring were typical of temperate regions with low influence of upwelling (e.g., Bode et al. 2011). Because of these oscillations, the prediction of PP from the wind regime at interannual time scales is problematic (Botsford et al. 2006), particularly in narrow shelves (as in Galicia) where intense upwelling will export plankton offshore.

The three quasi-decadal phases identified for $\mathrm{Chl}$ and $\mathrm{PP}$ in our time series were not matched by similar variations in upwelling. Trends and cycles in UI were analyzed regionally in several studies with diverse conclusions depending on the type of data and the length of the series (e.g., Santos et al. 2011). In fact, some of the studies in the area analyzed periods 
(a)

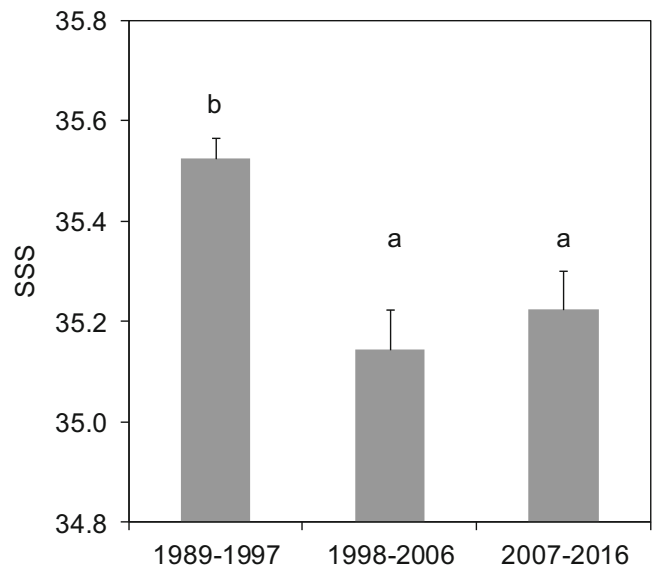

(b)

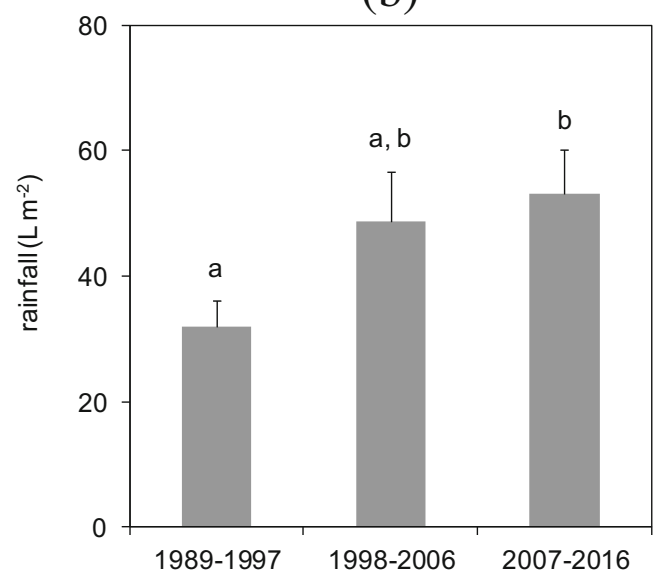

Fig. 7 Mean ( \pm SE) values of a sea surface salinity (SSS) and $\mathbf{b}$ rainfall $\left(1 \mathrm{~m}^{-2}\right)$ accumulated for 15 days prior to sampling during spring (February to May) for the phases identified in Fig. 1. The letters above each bar identify the significant groups (PERMANOVA and Bonferroni tests, $p<0.05$ )

ending around 2007, when upwelling was at its minimum, and consequently concluded that upwelling was reducing (Pérez et al., 2010). While the identification of dominant linear trends appears of less importance, taking into account the oscillating nature of the upwelling at all scales (Abrantes et al. 2011), our analysis stressed the importance of the annual frequency for both upwelling and $\mathrm{Chl}$ and PP series, along with the consideration of additional factors other than upwelling influencing phytoplankton productivity.

\subsection{Multiple drivers at the interannual scale}

Annually averaged Chl and PP values in our studied series were weakly correlated with nutrient concentrations and upwelling intensity. This result agrees with those found in previous studies (Bode et al. 2011) and with changes in phytoplankton species composition (Bode et al. 2015; Otero et al. 2018) in the same series, thus suggesting that ecosystem productivity in our area is not only driven by nutrients introduced in the system by upwelling. In fact, we have shown that changes in Chl and PP between phases were accompanied by changes in nutrient concentrations at certain seasons of the year, particularly with the input of low salinity water with high nutrient concentrations during the spring. Long-term changes in Chl were also described for nearby areas (Ria de Arousa) where nutrients provided by the upwelling were not the only source for primary production (Pérez et al. 2010).

The participation of additional nutrient sources in our series was evidenced by the positive anomalies of nutrient concentrations in the bottom layer of station E2CO during upwelling events (Online Resource 6). It is noticeable that most of the anomalies were positive, indicating an excess of nutrients over the ENACW inputs. Reference values for ENACW were computed from in situ data off-the-shelf in the period 1977 to 1998, and this fact can influence the sign of the anomaly. For instance, year-to-year changes in the source water properties at the formation sites (e.g., deep convective mixing during winter) would affect the nutrient concentrations (Hartman et al. 2014). However, no correspondence with the quasidecadal periods exhibited by Chl and PP series was observed in our estimation of variations in the nutrient content of upwelled waters. Therefore, the relative excess of nutrients observed must be caused by enhanced in situ remineralization of organic matter or by continental inputs in surface waters (as observed during spring).

Remineralization of organic matter provides a significant amount of nutrients in the Galician shelf. The export of coastal surface waters by the upwelling dynamics along with outflow of freshwater from the rias favors the accumulation of organic matter in the shelf and its conversion into inorganic nutrients (Alvarez-Salgado et al. 1997; Alvarez-Salgado et al. 2006). Diffusion of porewater and resuspension of sediments also contributes to the observed nutrient concentrations in shelf waters. One example of this influence can be the positive anomaly in silicate observed at $70 \mathrm{~m}$ during our study (Fig. 7). In the case of nitrogen, both biogeochemical estimations (Alvarez-Salgado et al. 1997) and uptake experiments (Bode et al. 2004) concluded that up to $50 \%$ of planktonic primary production of the Galician shelf can be due to regenerated nutrients. This additional input may contribute to explain the mismatch between upwelling and $\mathrm{Chl}$ trends observed in the present and past studies (e.g., Pérez et al. 2010). However, the contribution of remineralization to the nutrient content of shelf waters is expected to be maximum in autumn, reflecting the decomposition of organic matter during the productive spring and summer seasons (Alvarez-Salgado et al. 2006), while in our study, we have identified that low-salinity surface waters were an important source of additional nutrients during spring.

Coastal fronts produced by river plumes and runoff are frequent off NW Iberia during autumn, winter, and spring affecting the whole continental shelf (Otero et al. 2009). Low-salinity 
waters are associated with higher nutrient concentrations than those found in ENACW (Alvarez-Salgado et al. 2002; Bode et al. 2017), thus providing additional nutrients for phytoplankton growth. Furthermore, the vertical salinity gradient associated with the front favors the retention of phytoplankton cells in the photic layer and thus the increase in productivity. One example of the influence of low-salinity waters in our series was found in 2000, when the high rainfall levels recorded produced historical maximum discharges of freshwater in most Galician rivers (Otero et al. 2010), and can be traced as the marked period of low salinity/high nutrient concentrations affecting the whole water column of the studied station (Online Resource 2). Accordingly, primary production and chlorophyll concentrations showed increased values during the spring and summer in 2001 compared with those of the previous year (Fig. 1). Reduced upwelling and increased precipitation during 2000-2001 also favored the increase of zooplankton abundance in the nearby Ria de Vigo (Buttay et al. 2016). The observed decrease in salinity associated to an increase in rainfall and surface nutrients during the spring for the last decades suggests a major role of continental waters in supporting primary production in coastal waters. In contrast, summer upwelling events appeared as the major source of nutrients in the period before 1998, as spring rainfall was lower than in the last two decades.

Because in this study we measured short-term carbon uptake rates, our estimates of PP can be considered closer to gross rather than to net production (Williams 1993). In turn, Chl reflects only in part phytoplankton biomass, as it is affected by photoadaption, nutrients and grazing by herbivores (Behrenfeld et al. 2016) and thus represents past PP (Chavez et al. 2011). For these reasons, our results are not in contradiction with the high correlation expected between the estimates of new production resulting from upwelling-derived nutrients (Alvarez-Salgado et al. 2002) and stress the importance of short-term variability in Chl (Pérez et al. 2010; Bode et al. 2011; Alvarez et al. 2012) and nutrients in Galician coastal waters (Doval et al. 2016).

Time series observations in other EBUS also pointed out the increasing importance of other factors than upwelling in determining the ecosystem productivity. For instance, recent phytoplankton blooms in the coast of California were not directly related to upwelling (Kim et al. 2009), and anthropogenic nutrients were identified as a significant source for nearshore productivity (Howard et al. 2014). However, changes in productivity were also related to the interaction between nutrient increases caused by upwelling and decreases caused by enhanced mixing during winter, both related to climatic oscillations (Nezlin et al. 2017). Furthermore, changes in the whole food web were induced by trophic cascades as the result of the interaction of upwelling dynamics with alterations in the biomass proportions of grazers and phytoplankton (Cloern et al. 2007). Similar interactions can be expected in Galicia and in the S Bay of Biscay, as suggested by the results of the present study and those on zooplankton time series, where upwelling only explained part of the observed interannual variability (Bode et al. 2009; González-Gil et al. 2015; Buttay et al. 2016). Increases in zooplankton abundance and biomass between 1988 and 2006 at the station considered in this study were concurrent with increases in Chl (Bode et al. 2009), thus suggesting that the negative effect of grazing was compensated by the increase in regenerated nutrients.

Large-scale climate forcing affects local and regional weather conditions (e.g., upwelling intensity or precipitation) mainly by modifications of the wind regime. However, climate indices may not be necessarily linked to direct changes in the plankton, as exemplified by studies in Galicia (Bode et al. 2009, 2011, 2015; Buttay et al. 2016). While multiannual periods of plankton production are expected to be related to ENSO in the Pacific EBUS (Lavaniegos and Ohman 2007; Chavez et al. 2011), the effects of large climate perturbations at decadal scales in this and other ecosystems are not well resolved with the available time series (Malone et al. 2016). The three quasi-decadal phases in $\mathrm{Chl}$ and PP identified in the present study were related with significant alterations in local nutrient concentrations at intraseasonal scales, changes that were not directly linked with upwelling. Notwithstanding the major role of upwelling as driver of coastal productivity, our understanding of the functioning of these systems is evolving from the earlier paradigm of almost an exclusive dependence of upwelling (e.g., Dickson et al. 1988) to the increasing recognition that other factors are important. For instance, continental water inputs have been shown to be relevant in the dynamics of the upwelling system in Galicia (Otero et al. 2009, 2010) and in other temperate, rainy regions affected by ocasional episodes of river discharge like Oregon and central-southern Chile (Sobarzo et al. 2007). Therefore, the continuation of long-term series of in situ determinations of PP and phytoplankton composition, like those used in the present study, will contribute to reduce the large uncertainty in determining the spatial patterns and temporal trends in phytoplankton productivity and nutrient cycles of the upper ocean.

The impact of climate change on upwelling ecosystems has been assessed in several studies. Expected variations of the ecosystem are put forth in response to changes in upwelling wind intensity and its effect on production and offshore advection (Bakun 1990), to changes in source water origins (Rykaczewski and Dunne 2010) or even in thermocline depths (Bakun et al. 2015). However, our results of Chl and PP in an upwelling influenced shelf show that upwelling winds and even variations in source water origins do not explain the observed variability at multidecadal scales. The impact of nutrients from local runoff, with a potential contribution of remineralization in the rias, needs to be taken into account and in fact explains part of the multidecadal variability. Therefore, assessments of the impact of climate change in upwelling ecosystems need to take variations of runoff, especially in spring, into account. 
Acknowledgements We are grateful to the dedicated work of many ship crew, technicians, and scientists that made possible the collection of the time series observations employed in this study. Particularly, we thank Manuel Varela and Jorge Lorenzo (phytoplankton measurements), and Nicolás González and Rosario Carballo (nutrient analysis) for the initiation and sustaining of the series in earlier years.

Funding information This research was funded by project RADIALES of the Instituto Español de Oceanografia (Spain), which received complementary funding from Axencia Galega de Innovación (GAIN, Xunta de Galicia, Spain). MRV and AB contributed to this work supported by project MarRisk (Interreg POCTEP Spain Portugal, 0262 MARRISK 1 E).

Open Access This article is distributed under the terms of the Creative Commons Attribution 4.0 International License (http:// creativecommons.org/licenses/by/4.0/), which permits unrestricted use, distribution, and reproduction in any medium, provided you give appropriate credit to the original author(s) and the source, provide a link to the Creative Commons license, and indicate if changes were made.

\section{References}

Abrantes F, Rodrigues T, Montanari B, Santos C, Witt L, Lopes C, Voelker AHL (2011) Climate of the last millennium at the southern pole of the North Atlantic Oscillation: an inner-shelf sediment record of flooding and upwelling. Clim Res 48:261-280

Alvarez I, Gómez-Gesteira M, De Castro M, Dias JM (2008) Spatiotemporal evolution of upwelling regime along the western coast of the Iberian Peninsula. J Geophys Res 113. https://doi.org/ 10.1029/2008JC004744

Alvarez I, Lorenzo MN, de Castro M (2012) Analysis of chlorophyll a concentration along the Galician coast: seasonal variability and trends. ICES J Mar Sci 69:728-738

Alvarez-Salgado XA, Castro CG, Pérez FF, Fraga F (1997) Nutrient mineralization patterns in shelf waters of the Western Iberian upwelling. Cont Shelf Res 17:1247-1270

Alvarez-Salgado XA et al (2002) New production of the NW Iberian shelf during the upwelling season over the period 1982-1999. Deep-Sea Res 49:1725-1739

Alvarez-Salgado XA, Nieto-Cid M, Gago J, Brea S, Castro CG, Doval MD, Perez FF (2006) Stoichiometry of the degradation of dissolved and particulate biogenic organic matter in the NW Iberian upwelling. J Geophys Res (C Oceans) 111. https://doi.org/10.1029/ 2004JC002473

Arístegui J, Alvarez-Salgado XA, Barton ED, Figueiras FG, HernándezLeón S, Roy C, Santos AMP (2006) Chapter 23. Oceanography and fisheries of the Canary Current/Iberian region of the Eastern North Atlantic (18a, E). In: Robinson AR, Brink K (eds) The global coastal ocean: interdisciplinary regional studies and syntheses., vol 14 . The sea: ideas and observations on progress in the study of the seas. Harvard University Press, Boston, pp 877-931

Bakun A (1990) Global climate change and intensification of coastal upwelling. Science 247:198-201

Bakun A, Black BA, Bograd SJ, Garcia-Reyes M, Miller AJ, Rykaczewski RR, Sydeman WJ (2015) Anticipated effects of climate change on coastal upwelling ecosystems. Curr Clim Change Rep 1:85-93

Barton ED, Field DB, Roy C (2013) Canary current upwelling: more or less? Prog Oceanogr 116:167-178

Behrenfeld MJ, O’Malley RT, Siegel DA, McClain CR, Sarmiento JL, Feldman GC, Milligan AJ, Falkowski PG, Letelier RM, Boss ES
(2006) Climate-driven trends in contemporary ocean productivity. Nature 444:752-755

Behrenfeld MJ, O'Malley RT, Boss ES, Westberry TK, Graff JR, Halsey KH, Milligan AJ, Siegel DA, Brown MB (2016) Revaluating ocean warming impacts on global phytoplankton. Nat Clim Chang 6:323330

Benazzouz A, Demarcq H, González-Nuevo G (2015) Recent changes and trends of the upwelling intensity in the Canary Current Large Marine Ecosystem. In: Valdés L, Déniz-González I (eds) Oceanographic and biological features in the Canary Current Large Marine Ecosystem, vol 115. IOC Technical Series. IOCUNESCO, Paris, pp 321-330

Bode A, Varela M (1998) Mesoscale estimations of primary production in shelf waters: a case study in the Golfo Artabro (NW Spain). J Exp Mar Biol Ecol 229:111-131

Bode A, Barquero S, González N, Alvarez-Ossorio MT, Varela M (2004) Contribution of heterotrophic plankton to nitrogen regeneration in the upwelling ecosystem of A Coruña (NW Spain). J Plankton Res 26:1-18

Bode A, Alvarez-Ossorio MT, Cabanas JM, Miranda A, Varela M (2009) Recent trends in plankton and upwelling intensity off Galicia (NW Spain). Prog Oceanogr 83:342-350

Bode A, Anadón R, Morán XAG, Nogueira E, Teira E, Varela M (2011) Decadal variability in chlorophyll and primary production off NW Spain. Clim Res 48:293-305

Bode A, Estévez MG, Varela M, Vilar JA (2015) Annual trend patterns of phytoplankton species abundance belie homogeneous taxonomical group responses to climate in the NE Atlantic upwelling. Mar Environ Res 110:81-91

Bode A, Varela M, Prego R, Rozada F, Santos MD (2017) The relative effects of upwelling and river flow on the phytoplankton diversity patterns in the ria of A Coruña (NW Spain). Mar Biol 164: 93:DOI: 10.1007/s00227-00017-03126-00229

Botsford LW, Lawrence CA, Dever EP, Hastings A, Largier J (2006) Effects of variable winds on biological productivity on continental shelves in coastal upwelling systems. Deep-Sea Res II 53:31163140

Brown ZW, Arrigo KR (2012) Contrasting trends in sea ice and primary production in the Bering Sea and Arctic Ocean. ICES J Mar Sci 69: 1180-1193

Buttay L, Miranda A, Casas G, González-Quirós R, Nogueira E (2016) Long-term and seasonal zooplankton dynamics in the northwest Iberian shelf and its relationship with meteo-climatic and hydrographic variability. J Plankton Res 38:106-121

Cabré A, Marinov I, Leung S (2015) Consistent global responses of marine ecosystems to future climate change across the IPCC AR5 earth system models. Clim Dyn 45:1253-1280

Capone DG, Bronk DA, Mulholland MR, Carpenter EJ (2008) Nitrogen in the marine environment., Vol. Elsevier, Amsterdam

Capone DG, Hutchins DA (2013) Microbial biogeochemistry of coastal upwelling regimes in a changing ocean. Nat Geosci 6:711-717

Casabella N, Lorenzo MN, Taboada JJ (2014) Trends of the Galician upwelling in the context of climate change. J Sea Res 93:23-27

Casas B, Varela M, Canle M, González N, Bode A (1997) Seasonal variations of nutrients, seston and phytoplankton, and upwelling intensity off La Coruña (NW Spain). Estuar Coast Shelf Sci 44: $767-778$

Cazelles B, Chavez M, Berteaux D, Ménard F, Vik JO, Jenouvrier S, Stenseth NC (2008) Wavelet analysis of ecological time series. Oecologia 156:287-304

Chassot E, Bonhommeau S, Dulvy NK, Melin F, Watson R, Gascuel D, Le Pape O (2010) Global marine primary production constrains fisheries catches. Ecol Lett 13:495-505

Chavez FP, Messié M, Pennington JT (2011) Marine primary production in relation to climate variability and change. Annu Rev Mar Sci 3: $227-260$ 
Chust G, Allen JI, Bopp L, Schrum C, Holt J, Tsiaras K, Zavatarelli M, Chifflet M, Cannaby H, Dadou I, Daewel U, Wakelin SL, Machu E, Pushpadas D, Butenschon M, Artioli Y, Petihakis G, Smith C, Garçon V, Goubanova K, le Vu B, Fach BA, Salihoglu B, Clementi E, Irigoien X (2014) Biomass changes and trophic amplification of plankton in a warmer ocean. Glob Chang Biol 20:2124 2139

Cloern JA, Jassby AD, Thompson JK, Hieb KA (2007) A cold phase of the East Pacific triggers new phytoplankton blooms in San Francisco Bay. Proc Natl Acad Sci 104(47):18561-18565

Davis J (1986) Statistics and data analysis in geology. Willey and Sons, Singapur

Demarcq H (2009) Trends in primary production, sea surface temperature and wind in upwelling systems (1998-2007). Prog Oceanogr 83: 376-385

Dickson RR, Kelly PM, Colebrook JM, Wooster WS, Cushing DH (1988) North winds and production in the eastern North Atlantic. J Plankton Res 10:151-169

Doval MD, López A, Madriñán M (2016) Temporal variation and trends of inorganic nutrients in the coastal upwelling of the NW Spain (Atlantic Galician rías). J Sea Res 108:19-29

Ducklow HW, Fraser W, Meredith M, Stammerjohn S, Doney S, Martinson D, Sailley S, Schofield O, Steinberg D, Venables H, Amsler C (2013) West Antarctic peninsula. An ice-dependent coastal marine ecosystem in transition. Oceanography 26:190-203

González-Gil R, González Taboada F, Höffer J, Anadón R (2015) Winter mixing and coastal upwelling drive long-term changes in zooplankton in the Bay of Biscay (1993-2010). J Plankton Res 37:337-351

González-Nuevo G, Gago J, Cabanas JM (2014) Upwelling index: a powerful tool for marine research in the NW Iberian upwelling system. J Oper Oceanogr 7:45-55

Grasshoff K, Ehrhardt M, Kremling K (1983) Methods of seawater analysis, 2nd edn. Verlag Chemie, Weinheim

Hammer Ø, Harper DAT, Ryan PD (2001) PAST: paleontological statistics software package for education and data analysis. Palaeontol Electron 4(9). http://palaeo-electronica.org/2001 1/past/issue1 01. htm. Accessed 25 Sep 2018.

Hartman SE, Hartman MC, Hydes DJ, Jiang Z-P, Smythe-Wright D, González-Pola C (2014) Seasonal and inter-annual variability in nutrient supply in relation to mixing in the Bay of Biscay. DeepSea Res II 106:68-75

Heymans JJ, Shannon LJ, Jarre A (2004) Changes in the northern Benguela ecosystem over three decades: 1970s, 1980s, and 1990s. Ecol Model 172:175-195

Howard MDA, Sutula M, Caron DA, Chao Y, Farrara JD, Frenzel H, Jones B, Robertson G, McLaughlin K, Sengupta A (2014) Anthropogenic nutrient sources rival natural sources on small scales in the coastal waters of the Southern California Bight. Limnol Oceanogr 59:285-297

Ibañez F, Fromentin JM, Castel J (1993) Application of the cumulated function to the processing of chronological data in oceanography. Comptes Rendus L Acad Des Sci Ser Iii-Sci La Vie-Life Sci 316: 745-748

Jang CJ, Park J, Park T, Yoo S (2011) Response of the ocean mixed layer depth to global warming and its impact on primary production: a case for the North Pacific Ocean. ICES J Mar Sci 68:996-1007

Kim H-J, Miller AJ, McGowan J, Carter ML (2009) Coastal phytoplankton blooms in the Southern California Bight. Prog Oceanogr 82: 137-147

Kvale KF, Meissner KJ, Keller DP (2015) Potential increasing dominance of heterotrophy in the global ocean. Environ Res Lett 10. https://doi. org/10.1088/1748-9326/1010/1087/074009

Large WG, Danabasoglu G (2006) Attribution and impacts of upperocean biases in CCSM3. J Clim 19:2325-2346
Lavaniegos BE, Ohman MD (2007) Coherence of long-term variations of zooplankton in two sectors of the California Current System. Prog Oceanogr 75:42-69

Lopez-Urrutia A, San Martin E, Harris R, Irigoien X (2006) Scaling the metabolic balance of the oceans. Proc Natl Acad Sci U S A 103: 8739-8744

Malone TC et al (2016) Chapter 6. Primary production, cycling of nutrients, surface layer and plankton. In: Inniss L, Simcock A (eds) The first global integrated marine assessment. United Nations, New York, p 67

Mantyla AW, Bograd SJ, Venrick EL (2008) Patterns and controls of chlorophyll-a and primary productivity cycles in the Southern California Bight. J Mar Syst 73:48-60

McGregor HV, Dima M, Fischer HW, Mulitza S (2007) Rapid 20thcentury increase in coastal upwelling off Northwest Africa. Science 315:637-639

Messié M, Ledesma J, Kolber DD, Michisaki RP, Foley DG, Chavez FP (2009) Potential new production estimates in four eastern boundary upwelling ecosystems. Prog Oceanogr 83:151-158

Neveux J, Panouse M (1987) Spectrofluorometric determination of chlorophylls and pheophytins. Arch Hydrobiol 109:567-581

Nezlin NP et al (2017) Spatial and temporal patterns of chlorophyll concentration in the Southern California Bight. J Geophys Res Oceans 123:231-245

Nogueira E, Pérez FF, Ríos AF (1997) Modelling thermohaline properties in an estuarine upwelling ecosystem (Ria de Vigo; NW Spain) using Box-Jenkins transfer function models. Estuar Coast Shelf Sci 44: 685-702

Otero P, Ruiz-Villarreal M, Peliz A (2009) River plume fronts off NW Iberia from satellite observations and model data. ICES J Mar Sci 66:1853-1864

Otero P, Ruiz-Villarreal M, Peliz A, Cabanas JM (2010) Climatology and reconstruction of runoff time series in northwest Iberia: influence in the shelf buoyancy budget off Ria de Vigo. Sci Mar (Barc) 74:267274

Otero J, Bode A, Álvarez-Salgado XA, Varela M (2018) Role of functional traits variability in the response of individual phytoplankton species to changing environmental conditions in a coastal upwelling zone. Mar Ecol Prog Ser 2018:33-47

Pardo PC, Padín XA, Gilcoto M, Farina-Busto L, Pérez FF (2011) Evolution of upwelling systems coupled to the long-term variability in sea surface temperature and Ekman transport. Clim Res 48:231246

Parsons TR, Maita Y, Lalli CM (1984) A manual of chemical and biological methods for seawater analysis. Pergamon Press, Oxford

Pauly D, Christensen V (1995) Primary production required to sustain global fisheries. Nature 374:255-257

Pérez FF, Padin XA, Pazos Y, Gilcoto M, Cabanas M, Pardo PC, Doval MD, Farina-Bustos L (2010) Plankton response to weakening of the Iberian coastal upwelling. Glob Chang Biol 16:1258-1267

Picado A, Lorenzo N, Alvarez I, deCastro M, Vaz N, Dias JM (2015) Upwelling and Chl-a spatiotemporal variability along the Galician coast: dependence on circulation weather types. Int J Climatol 36: 3280-3296

Piedracoba S, Nieto-Cid M, Souto C, Gilcoto M, Rosón G, ÁlvarezSalgado XA, Varela R, Figueiras FG (2008) Physical-biological coupling in the coastal upwelling system of the Ría de Vigo (NW Spain). I: in situ approach. Mar Ecol Prog Ser 353:27-40

Williams PJ (1993) On the definition of plankton production terms. ICES Mar Sci Symp 197:9-19

Polovina JJ, Howell EA, Abecassis M (2008) Ocean's least productive waters are expanding. Geophys Res Lett 35. https://doi.org/10.1029/ 2007GL031745

Rykaczewski RR, Dunne JP (2010) Enhanced nutrient supply to the California Current Ecosystem with global warming and increased 
stratification in an earth system model. Geophys Res Lett 37: L21606

Rykaczewski RR, Dunne JP, Sydeman WJ, García-Reyes M, Black BA, Bograd SJ (2015) Poleward displacement of coastal upwellingfavorable winds in the ocean's eastern boundary currents through the 21st century. Geophys Res Lett 42:6424-6431. https://doi.org/ 10.1002/2015GL064694

Santos F, Gómez-Gesteira M, deCastro M, Álvarez I (2011) Upwelling along the western coast of the Iberian Peninsula: dependence of trends on fitting strategy. Clim Res 48:213-218

Silva A, Palma S, Oliveira PB, Moita MT (2009) Composition and interannual variability of phytoplankton in a coastal upwelling region (Lisbon Bay, Portugal). J Sea Res 62:238-249

Sobarzo M, Bravo L, Donoso D, Garcés-Vargas J, Schneider W (2007) Coastal upwelling and seasonal cycles that influence the water column over the continental shelf off Central Chile. Prog Oceanogr 75:363-382

Torrence C, Compo GP (1998) A practical guide to wavelet analysis. Bull Am Meteorol Soc 79:61-78

Tremblay J-É, Gagnon J (2009) The effects of irradiance and nutrient supply on the productivity of Arctic waters: a perspective on climate change. In: Nihoul JCJ, Kostianoy AG (eds) Influence of climate change on the changing Arctic and sub-Arctic conditions. Springer, Dordrecht, pp 73-92

Watson RA, Nowara GB, Hartmann K, Green BS, Tracey SR, Carter CG (2015) Marine foods sourced from farther as their use of global ocean primary production increases. Nature Comm 6(7365):7365. https://doi.org/10.1038/ncomms 8365

Zuur AF, Ieno EN, Elphick CS (2010) A protocol for data exploration to avoid common statistical problems. Methods Ecol Evol 1:3-14 